Bangladesh J. Plant Taxon. 16(2): 185-194, 2009 (December)

(c) 2009 Bangladesh Association of Plant Taxonomists

\title{
TAXONOMIC STRUCTURE OF THE ALGAL FLORA OF IRAN
}

\author{
B. ZAREI-DARKI ${ }^{1}$ \\ Department of Biology, Islamic Azad University, Falavarjan Branche, Esfahan, Iran. \\ Keywords: Algal flora; Taxonomic quotient; Water body; Iran.
}

\begin{abstract}
Algal floristic work carried out in Iran between 1853 and 1981 have been reviewed and compared with the results obtained in a series of recent studies (2000-2007). Algal samples for the recent studies were collected mainly from different inland aquatic habitats. On the basis of data from published and the recent studies, the systematic list of algae shows the occurrence of 1304 species and 1559 infra-specific taxa in Iran. However, 1213 species (1443 infra-specific taxa) revealed from the recent studies included 812 species (979 infra-specific taxa) as new reports for Iran (63\% of the total species recorded). Analysis on taxonomic structure of algal flora of Iran testifies its richness. The basic parameters of a regular diversification of flora, values of genera quotient, spectra of leading taxa confirm that the highest percentage is contributed by Bacillariophyta (43\%) of the total number of specific and infra-specific taxa followed by Chlorophyta (25\%), Cyanophyta (15\%) and Euglenophyta (8\%). On an interrelation among divisions of algae, the algal flora of Iran appeared to be closer to that of Turkmenistan.
\end{abstract}

\section{Introduction}

Preserving biological diversity needs research on species richness of certain taxonomic groups in different administrative and natural territories. So far, the algal diversity of Iran has been investigated very insufficiently. According to Compere (1981) L. Rabenhorst (1853) reported first several species of freshwater diatoms (Bacillariophyta) from South Persia, Iran but without mentioning habitats. In 1842, soil samples were collected by Kotschy from the territories between Percipolis, Shiraz and Bushehr which cover modern provinces, namely Fars, Esfahan, Bahtiaria and Cheharmehal, Busher. Later Ehrenberg studied them and revealed 45 species of algae (Ehrenberg, 1854), out of which, 29 species became valid. In 1899, J.B. Petersen identified 8 species of algae studying samples collected by O. Paulsen from the Purlieus of Tehran (Petersen, 1930). Later on, D.A. Tarnogradskiy collected 9 samples from the Anzali Swamp in November 1922 and Woronichin (1925) published 13 species of algae from those collections.

The first remarkable studies on the algal flora of Iran by Löffler $(1959,1961)$ appeared 100 years after the very first report by Rabenhorst (l.c.). The works of Löffler can be considered as the first authentic study on the algal flora of Iran. Later on, Hirano (1973) and Wasylik (1975) reported 406 infra-specific taxa. From the soil algae of Sahara-Gobi desert area, 29 species from the arid soils have been mentioned for Iran (Novichkova-Ivanova, 1980).

\footnotetext{
1E-mail: zareidarki@iaufala.ac.ir; zarei@mail.ru
} 
In autumn of 1972, the Belgian multi-purpose expedition investigated deserts of the central, eastern and middle Iran, mainly Dašt-e Kavir, Dašt-e Lut and hollow Jazmuriyãn. Botanist of the above-mentioned expedition J. Leonard collected samples of algae, which became a subject of study in P. Compere's work (Compere, 1981). The samples of algae were collected from 21 different places and about 300 species and varieties were presented. Of these $66 \%$ was diatom, $17 \%$ green and $14 \%$ blue-green algae. Two species of diatom Nitzschia curvata Compere, N. iranica Compere and one form Navicula egregia Hust. fa. elongata Compere were described as new to science (Compere, 1981). Till 2000, an estimated 580 algal taxa were known from Iran.

A series of studies on algae of Iran was conducted between 2000 and 2007 based on 535 samples collected from 125 water bodies from all over Iran (Dogadina et al. 2002; Zarei-Darki, 2002, 2004 a, b, 2006, 2007). The habitats included 64 rivers, 19 reservoirs, 19 ponds, 7 lakes, 2 swamps, 2 Karizes (a kind of artificial underground channel), 2 water-falls, and 10 springs of which 6 were thermal with water temperature ranged from $34-52^{\circ} \mathrm{C}$ (Fig. 1).

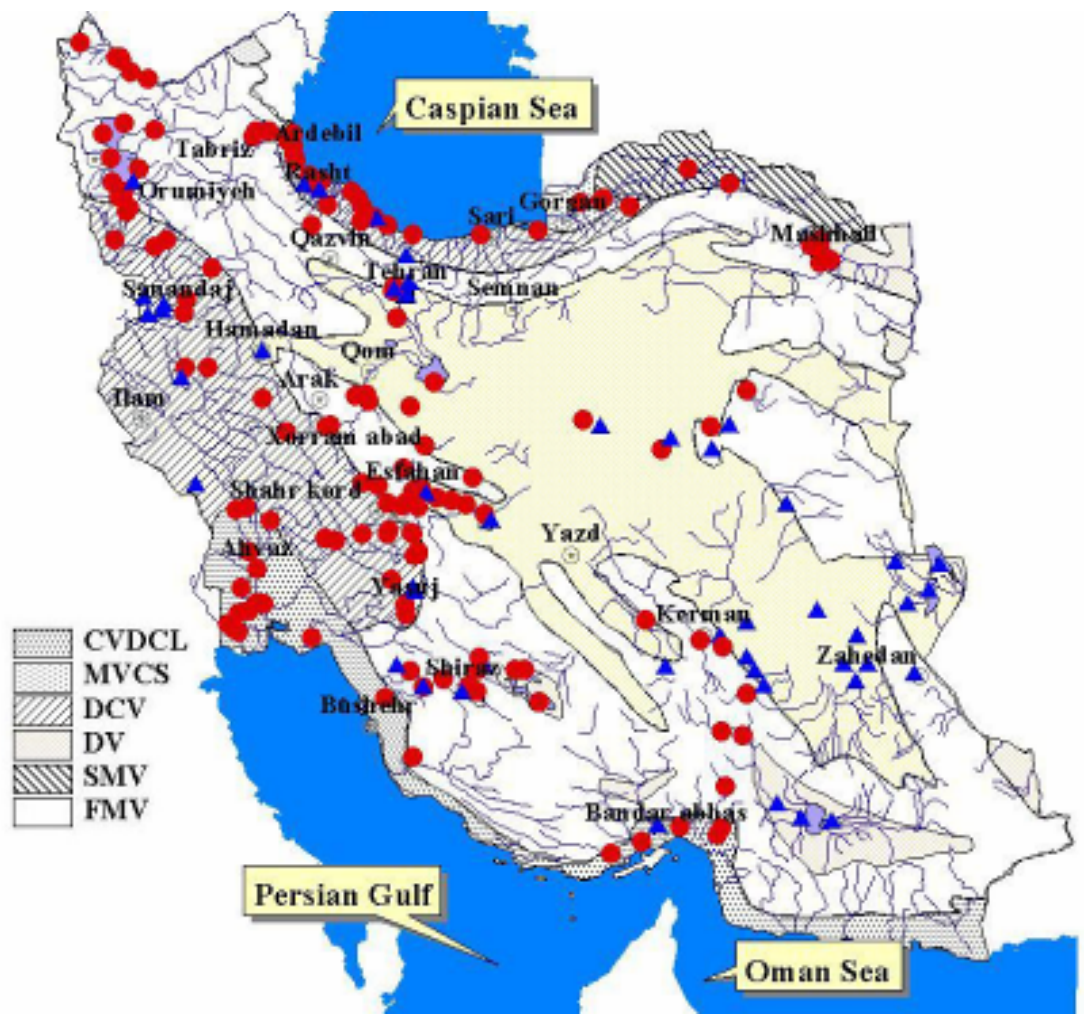

Fig. 1. Schematic map of Iran with sampling sites: deciduous vegetation (DCV), steppe mountain vegetation (SMV), friganoid mountain vegetation (FMV), desert vegetation (DV), complex vegetation of deserted coastal lowlands (CVDCL), meadow-salt marsh vegetation of southern coast of Caspian sea (MVCS), • - author's collections (2000-2007); $\boldsymbol{\Delta}$ - the literary data. 
The present paper attempts to analyze the taxonomic structure of algal flora of Iran based upon published information starting from L. Rabenhorst to P. Compere (18531981) and also data obtained from recent studies based upon samples collected between 2000 and 2007 by the author. The algal flora of Georgia (Chkhaidze, 1987), Turkmenistan (Kogan, 1973), Central Asia (Muzafarov, 1965), Vietnam (Tien, 1982) and Ukraine (Wasser and Tsarenko, 2000; Tsarenko and Petlevanniy, 2001) were also compared with that of Iran.

\section{Overall algal diversity of Iran}

Algae from different water bodies of Iran revealed the occurrence of 1213 species and 1443 infra-specific taxa (infra-specific taxa), which included 812 species (979 infraspecific taxa) as new report for Iran (about $63 \%$ of the general species diversity). But 91 algal species (116 infra-specific taxa) from the previous studies on the territorial boundary of Iran could not be confirmed in the recent studies. So, by adding 91 species and 116 infra-specific taxa as obtained from the literature survey to the data accumulated in the recent studies, the total number of algal species now reached 1304 (1559 infraspecific taxa) for Iran (Table 1). The algal species of Iran belong to 8 divisions, 15 classes, 37 orders, 96 families and 262 genera (Table 1). Among the divisions, Bacillariophyta is the largest followed by Chlorophyta, Cyanophyta and Euglenophyta. The percentage of each division is given in Table 2. In the following sections, classification of Zerov (1972) is followed.

\section{Diversity within algal divisions}

Cyanophyta has made up almost $15 \%$ of the total number of specific and infraspecific taxa of Iran (Table 2). The recent studies revealed 174 species including 201 infra-specific taxa. About 126 taxa appeared as new reports from Iran. From literary data the wide-spread cyanophytic species belonged to the genera Gloeocapsa (Kütz.) Hollerb., Merismopedia (Meyen) Elenk., Microcystis (Kütz.) Elenk., Oscillatoria Vauch., Phormidium Kütz. and Synechocystis Sauv. Some sporadically recorded cyanophytes are Synechocystis pevalekii Erceg. (Parišãn Lake), Microcystis testacea (Näg.) Elenk. (Lirbāzār rudgā River), Aphanothece nostocopsis Skuja (Parišãn Lake), Chamaesiphon incrustans Grun. (Toroq Reservoir), Phormidium paulsenianum Boye-Pet. (Orumiyeh Lake), Ph. toficola (Näg.) Gom (Šatt-e mongãr Lake), Microcoleus sociatus W. et G.S. West (Mahallãt Thermal spring), Anabaena azollae Straburg (Anzali Swamp), and Rivularia aquatica (de Wild.) Geitl. (Vošmgir Reservoir).

Euglenophyta is the fourth largest division in Iran in terms of species and infraspecific numbers. In the research conducted during 2000-2007, 121 euglenoid taxa were recorded as new reports. Earlier, four species of euglenoid algae recorded by Wasylik (1975) and Compere (1981) were also found to occur in the present investigation. 


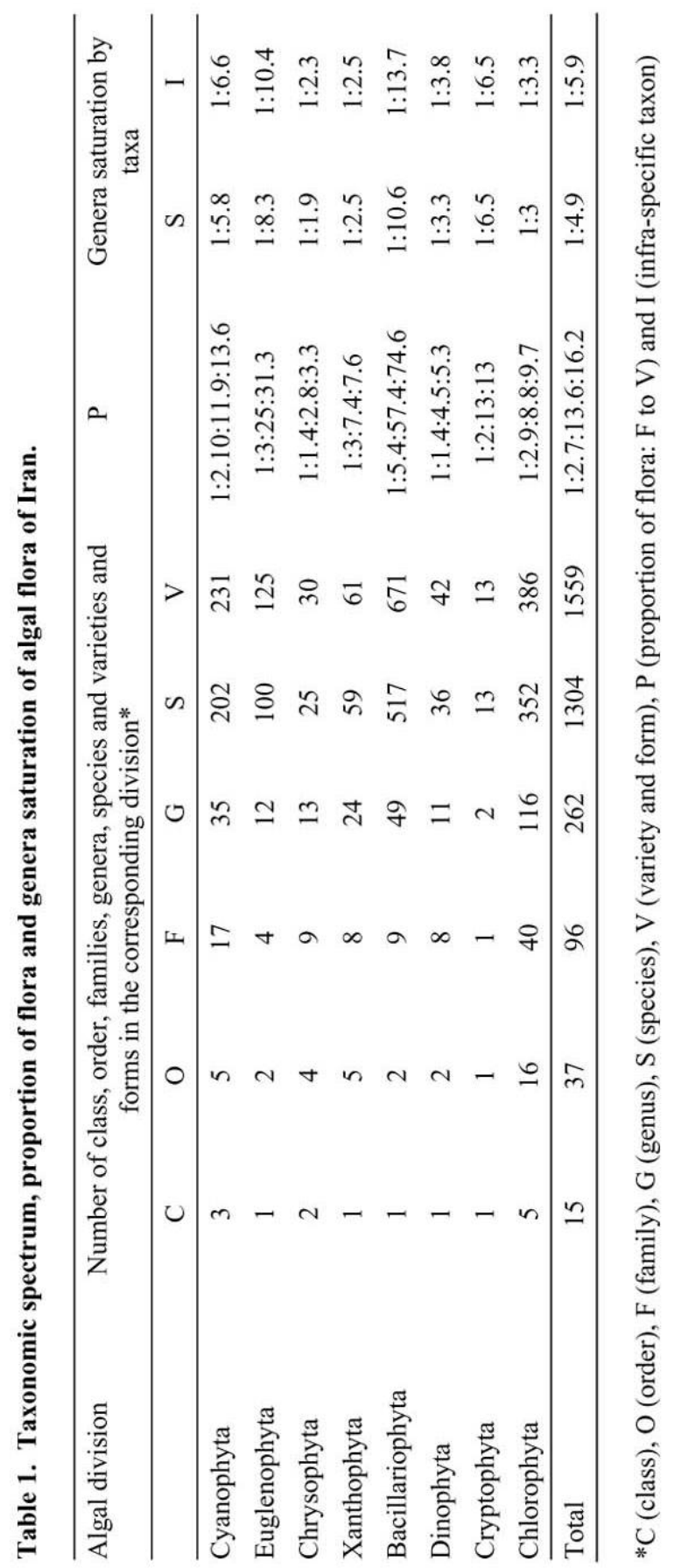




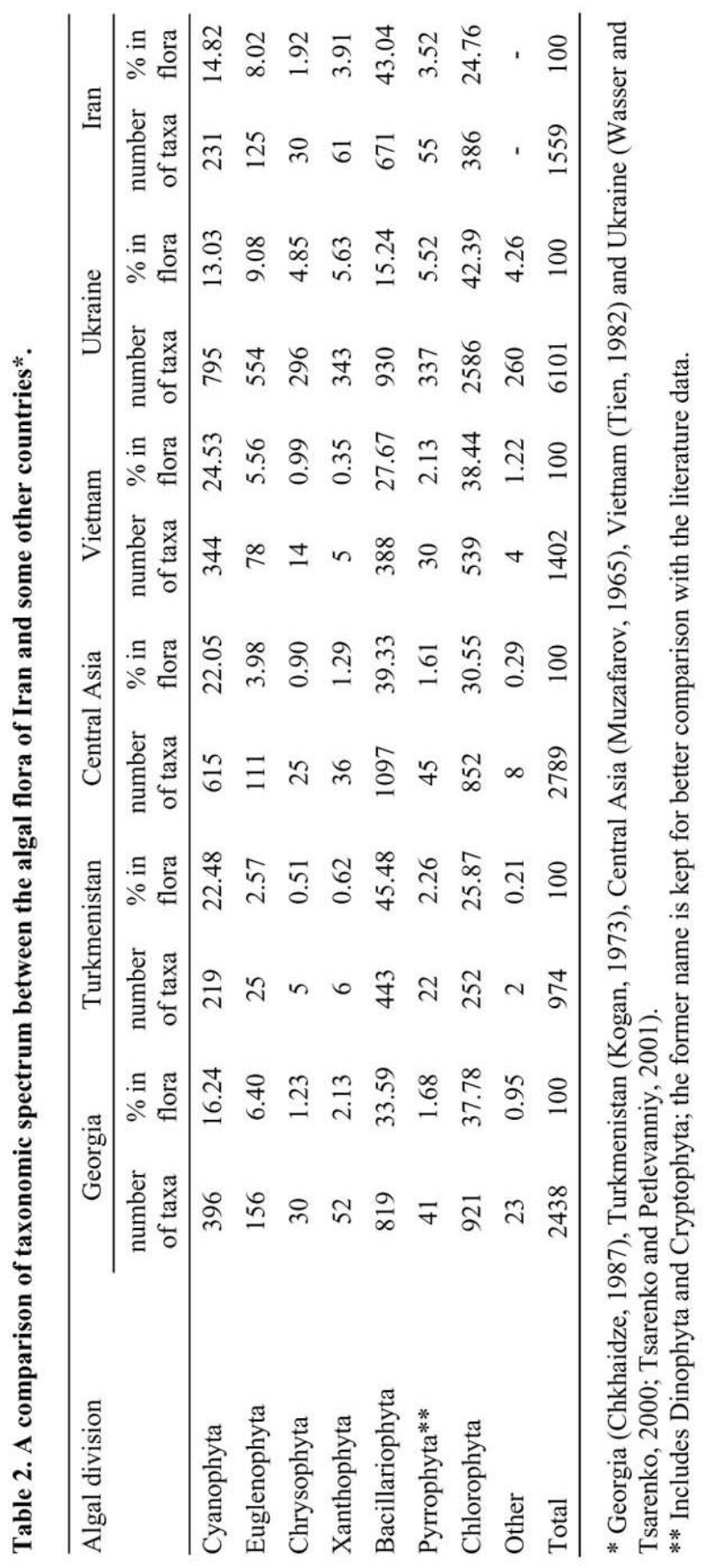


Euglena anabaena Mainx was found only in Halil rud River and E. mutabilis Schmitz was recorded both from Halil rud and Minãb Rivers; while E. oxyuris Schmarda in a number of rivers, reservoirs, ponds and swamp habitats (water temperature $16-28^{\circ} \mathrm{C}, \mathrm{pH}$ 6.5-8.0). Trachelomonas hispida (Perty) Stein emend. Defl. var. duplex Defl. occurred in Qešlāq River and Hasanlu Reservoir.

The occurrence of Chrysophyta is known only from the recent studies. The most frequently occurring and wide-spread species are Dinobryon divergens Imhof., Kephyrion rubri-claustri Conr. and Lagynion triangulare (Stokes) Pasch. Occasionally occurring species include Chrysococcus ornatus Pasch., Dinobryon sertularia Ehr., D. sociale Ehr., Kephyrion valkanovii Huber-Pest. and Pseudokephyrion schilleri (Schill.) Conr.

Altogether 56 species and 58 infra-specific taxa of Xanthophyta have been recorded in the recent studies; but the occurrence of species like Botrydiopsis eriensis Snow, Botryochloris minima Pasch. (Novichkova-Ivanova, 1980) and Vaucheria sessilis (Vauch.) D.C. (Woronichin, 1925) reported in previous studies could not be confirmed. The majority of Xanthophyta representatives was noted seldom, and a few of these species, namely Arachnochloris striata Pasch., Chlorothecium clava Pasch., Stipitococcus apiculatus Prescott and Tetraedriella impressa Pasch., were recorded only in Šãdgãn Pond, and Mohammad ãbãd and Sivand Rivers, and Anzali Swamp, respectively.

Diatoms (Bacillariophyta) dominated in all the investigated water bodies of Iran. More than $90 \%$ of species and infra-species (i.e. 479 species and 612 infra-specific taxa) were revealed by the recent studies with 217 species (303 infra-specific taxa) as new records for Iran. Some of the newly recorded diatom species of Iran are Aulacoseira italica (Ehr.) Sim., Cyclotella bodanica Grun., C. caspia Grun., Diatoma ehrenbergii Kütz., Eunotia diodon Ehr., Melosira lineate Ag., M. undulata (Ehr.) Kütz. var. normannii Arn., Stephanodiscus astraea (Ehr.) Grun., Synedra gaillonii (Bory) Ehr. and Thalassiosira bramaputrae (Ehr.) Hak.

Out of 36 species of dinophytes, only two were known before (Löffler, 1961; Wasylik, 1975), namely Ceratium hirundinella (O. Müll.) Bergh. and Peridiniopsis oculatum (Stein) Bourr. Dinophytes represented in the plankton of Qešlāq River and Reservoir, Sanandaj City were Glenodinium lemmermannii Zach., Gonyaulax polyedra Stein, Gymnodinium palustre Schill., Peridiniopsis charkowiensis (Matv.) Bourr., P. oculatum (Stein) Bourr., Peridinium aciculiferum Lemm. and $P$. pseudolaeve Lef.

No species of Cryptophyta was recorded for Iran before the recent studies. Most frequent cryptophytes are Chroomonas acuta Uterm., Ch. coerulea (Geitl). Skuja, Ch. rosenbergae Hub.-Pest., Cryptomonas borealis Skuja, C. marssonii Skuja and $C$. parapyrenoidifera Skuja. 
Chlorophyta is the second largest algal division in Iran. Class Chlorophyceae occupies leading position among other classes of green algae and is represented by 9 orders, 27 families, 209 species and 221 infra-specific taxa. As a result of processing samples from polytypic water bodies of Iran during 2000-2007, 200 species (211 infraspecific taxa) were identified, of them 165 species (176 infra-specific taxa) are new for the country. Frequently occurring species are Chlamydomonas angulosa Dill, Ch. snowiae Printz, Coelastrum microporum Näg. in A. Br., Dunaliella minuta Lerche, Kirchneriella irregularis (G. Sm.) Korsch., Micractinium pusillum Fres., Monoraphidium irregulare (G. Sm.) Kom.-Legn. in Fott, Oocystis borgei Snow, Pediastrum boryanum (Turp). Menegh., Planctococcus sphaerocystiformis Korsch., Scenedesmus acuminatus (Lagerh.) Chod., S. ellipticus (W. et G. S. West) Chod., S. quadricauda (Turp.) Breb., Schroederia setigera (Schröd.) Lemm., Tetraedron minimum (A. Br.) Hansg. and Tetrastrum triangulare (Chod.) Kom. From the order Chlorodendrales under the class Prasinophyceae, two species, namely Tetraselmis arnoldii (Pr.-Lavr.) Norris, Hori \& Chihara and $T$. contracta (Carter) Butcher, were recorded from rivers, reservoirs and swamps.

Among the new findings from Ulvophyceae, noteworthy species are Geminellopsis fragilis Korsch., Klebsormidium dissectum (Gay) Ettl et Gärtn., Stichococcus bacillaris Näg., Ulothrix flacca (Dilw.) Thur., U. zonata (Web. et Mohr.) Kütz. and Uronema confervicolum Lagerh.

From Zygnematophyceae, Mougeotia sphaerocarpa Wolle, Spirogyra bogeana Trans., S. condensata (Vauch). Kütz., S. ellipsospora Trans., S. micropunctata Jao, S. pratensis Trans., Zygnema insigne (Hass.) Kütz. and Z. pectinatum (Vauch.) Ag. have been recorded for the first time in Iran during recent studies.

Charophyceae known earlier (Compere, 1981) have also been found to occur during the recent studies. Chara gymnophylla A. Br. was found to grow within water temperature $14-28^{\circ} \mathrm{C}, \mathrm{pH}$ 6.5-7.0 in the Halil rud River and Šatt-e mongãr Lake, and $C h$. vulgaris L. emend. Wallr. in Halil Rud River, Šãdgãn Pond and Gãvxuni Swamp (14-28 ${ }^{\circ} \mathrm{C}$, pH 6.5-8.5). For the first time in Iran, Chara uzbekistanica Hollerb. was found in the Šatt-e mongãr Lake and Gãvxuni Swamp $\left(20-28^{\circ} \mathrm{C}, \mathrm{pH}\right.$ 6.5-8.5). However, Nitella hyalina (DC.) Ag. could not be recorded in the recent studies.

\section{Taxonomic quotients}

It is known that the factor which testifies connection between number of species, genera and families determines the 'face' of flora with the greatest clarity (Tolmachev, 1974). 'Proportions of flora' and generic factor concern to a group of parameters of taxonomic diversity. The $\mathrm{s} / \mathrm{f}$ (species/families) is estimated as a ratio between the number of species and number of family of a particular group (e.g. class); g/f (genera/families) and s/g (species/genera) are determined in a like manner. Generic factor shows generic 
richness of algal flora by species and infra-specific taxa. According to some authors, richer floras differ from less rich floras by higher values of these parameters (Shmidt, $1980,1984)$. Additionally, generic factor is considered as a factor of taxonomic diversity that does not depend on area.

Comparison of genera quotient values among divisions shows that the greatest specific richness is seen in Bacillariophyta followed by Euglenophyta, Cryptophyta and Cyanophyta (Table 1). In spite of high number of species in algal flora, Chlorophyta occupies sixth place. Apparently, it is explained by the presence of the large number of genera with little species number, e.g. 84 genera represented only by one or two species out of 116 total genera in Iran's algal flora.

For the algal flora of Iran as a whole, rather high values of general genera quotient (4.9) (Table 1) testifies the richness of investigated flora. Such conclusion is proved to be true by the comparison of values of the genera quotient for some other floras. For example, genera quotient was 2.8 for system of lake Chany (Safonova, 1973), and 3.8 for water bodies of Yakutia (Vasilieva, 1989).

\section{Comparison of algal flora of Iran with those of other countries}

Table 2 shows a comparison of taxonomic spectrum of algal flora of different countries with that of Iran. The choice of the countries was arbitrary. The only generalized data brought in the literature (Muzafarov, 1965; Kogan, 1973; Tien, 1982; Chkhaidze, 1987; Wasser and Tsarenko, 2000; Tsarenko and Petlevanniy, 2001) were used in the paper. The compared countries and regions rather differ on the terrain, natural settings, remoteness from Iran, a degree of a level of algal flora knowledge and many other attributes. However, ostensibly such comparison is useful to reveal general regularity and characteristic features in the algal structures of these regions.

Absolute values of all comparable floras differ markedly and indeed depend on degree of algal study in the country. Therefore, proportion (in \%) a division occupies in the total algal flora was preferred than its absolute value.

In all the compared floras as presented in Table 2, the basic role is played by two divisions, namely Chlorophyta and Bacillariophyta, occupying top two positions in taxonomic spectra. Contribution of these two divisions in the algal flora of Iran looks very close to the algal flora of Turkmenistan. This can be explained by the geographical location and presence of the general orographical and climatic attributes of the two countries. In other floras, the $1^{\text {st }}$ place is occupied by the green algae considerably leaving behind diatoms as it is evident in the flora of Ukraine range. In all the compared floras, the $3^{\text {rd }}$ place in taxonomic spectra is occupied by blue-green algae. It is evident that the diversity of Cyanophyta in some neighboring geographical regions (Turkmenistan, Central Asia) is very high compared with Iran. But contrary to it, in Iran, luxuriant growth of Cyanophyta is common in the rice fields and obviously a study on these 
habitats could add a few more taxa to the list of Iran. Parameters of the relative contribution on other divisions of algae when compared, the data obtained for Iran shows a concurrence with the data of other floras in most cases.

\section{Acknowledgement}

The author expresses sincere gratitude to Prof. T.V. Dogadina under whose direction the present piece of research was carried out.

\section{References}

Chkhaidze, R.I. 1987. Material k analizu algoflory Gruzii (Material to analyze of algal flora of Georgia). Tez. dokl. Vsesous. Conf. “Aktualnie problem sovremennoy algologii”. Nauk. Dumaka, Kiev, pp. 1-82. (in Russian)

Compere, P. 1981. Algues des déserts d'Iran. Bull. Jard. Bot. Nat. Belg, Belgia 51: 3-40.

Dogadina, T.V., Zarei Darki, B. and Gorbulin, O.S. 2002. Algae of Anzali Swamp (Iran). Int. Journal on Algae 4(4): 81-87

Ehrenberg, C. G. 1854. Mikrogeologie, Texte. E. Kummer, Leipzig, pp. 111-116.

Hirano, M. 1973. Freshwater algae from Mesopotamia. Contr. Biol. Lab. Kyoto Univ. 24(2): 105-119.

Kogan, Sh.I. 1973. Vodorosli vodoemov Turkmenskoi SSR (Algae of the water bodies of Turkmenian SSR). Ylym, Ashhabad, pp. 1-212. (in Russian)

Löffler, H. 1959. Beiträge zur Kenntnis der Iranischen Binnengewässer. Int. Rev. Ges. Hydrobiologia 44(1): 227-276.

Löffler, H. 1961. Beiträge zur Kenntnis der Iranischen Binnengewässer. Int. Rev. Ges. Hydrobiologia 46(2): 309-406.

Muzafarov, A.M. 1965. Flora vodoroslei vodoemov Srednei Azii (Algal flora of the water bodies of Middle Asia). Nauka. Tashkent, pp. 1-571. (in Russian)

Novichkova-Ivanova, L.N. 1980. Pochvennye vodorosli fitocenozov Saharo-Gobiiskoi pustynnoi oblasti (Soil algae of Sahara-Gobi desert region). Nauka. Leningrad, pp. 1-256. (in Russian)

Petersen, J.B. 1930. Algae from O. Olufsen's second Danish Pamir Expedition 1898-1899. Dansk. Bot. Ark. 6(6): $1-60$.

Rabenhorst L. 1853. Die Süsswasser-Diatomaceen. E. Kummer, Leipzig, pp. 1-72 + pls 1-10.

Safonova, T.A. 1973. Sovremennoe sostoyanie izuchennosti algoflori Zapadnoy Sibiri (Modern condition of a level of study of algal flora in the western Siberia). AN SSSR Vsesouz. Botan. obsh., Leningrad, pp. 196. (in Russian)

Shmidt, V.M. 1980. Statisticheskie metody v sravnitelnoy floristike (Statistical methods of comparative floristic). Publishing house LGU, Leningrad, pp. 1-176. (in Russian)

Shmidt, V.M. 1984. Matematicheskie metody v botanike (Mathematical methods of Botany). Publishing House LGU, Leningrad, pp. 1-288. (in Russian)

Tien, Z.D. 1982. Flora vodorosley vodoemov Vietnama (Algal flora of water bodies in the Vietnam). Abstract of PhD Thesis, Institute of Botany A. Sc Uzbekistan. Tashkent, pp. 1-474. (in Russian)

Tolmachev, A.I. 1974. Vvedenie v geografiyu rasteniy (Introduction to geography of plants). Publishing House LGU, Leningrad, pp. 1-243. (in Russian) 
Tsarenko, P.M. and Petlevanniy, O.A. 2001. Dopolnenie k raznoobraziyu vodorosley Ukrainy (Addition to diversity of algae of Ukraine). Kholodny Int. of Botany Nat. A. Sc. Ukraine, pp. 1-130. (in Russian)

Vasilieva, I.I. 1989. Vodorosli vodoemov criolitozony SSSR: sistematicheskiy sostav, ekologia, rasprostranenie (na primere Yakutii) (Algae of water bodies in cryolite zone of USSR: taxonomic composition, ecology, distribution). Kishenev, pp. 1-50. (in Russian)

Wasser, S.P. (ed.) and Tsarenko, P.M. 2000. Raznoobrazie vodoroslei Ukrainy (Diversity of algae in the Ukraine). Algologia 10(4): 1-309. (in Russian)

Wasylik, K. 1975. Notes on the freshwater algae of Iran. Fragm. Flor. Geobot. 21(3): 369-397.

Woronichin, N.N. 1925. Spisok presnovodnyh vodoroslei, sobrannyh D.A. Tarnogradskim v okrestnostyah bolota Enzeli (List of freshwater algae collected by D.A. Tarnogradskiy in the neighbourhood of Anzali swamp). Travaux de la station Biologique du Caucase du Nord 1(1): 43-44. (in Russian)

Zarei Darki, B. 2002. Algae of biological ponds (Esfahan province, Iran). Bull. Kharkiv Nat. Agr. Univ. Ser. Biology, Kharkiv, 9(1): 96-101.

Zarei Darki, B. 2004a. Algae of water bodies of Iran. PhD Thesis, Kholodny Int. of botany Nat. A. Sc. Ukraine. Kiev, pp. 1-664.

Zarei Darki B. 2004b. Chrysophyta of water bodies of Iran. Int. Journal on Algae 6(1): 12-20.

Zarei Darki, B. 2006. Bacillariophyta vodoemov Irana (Bacillariophyta of water bodies of Iran). Algologia 16(2): 246-260. (in Russian)

Zarei Darki, B. 2007. Diatomic algae of lakes of Iran. Proceedings of International Conference of Youth Scientists on 'Actual problems of phycology', Kiev, Ukraine, 17-21 October 2007, pp. 34-35.

Zerov, D.K. 1972. Ocherk phylogenii bessosudictykh rasteniy (Phylogenetic sketch of the avascular plants). Naukova dumka Press, Kiev, pp. 1-316. (in Russian) 